Journal of Research in Technical Careers

December 2020, Vol. 4, No. 2.

(C) Author(s)

\title{
Potential Mentoring Impacts on Oklahoma Induction- Year School-Based Agricultural Education Teachers: A Modified Delphi Study
}

\author{
Jessica M. Toombs, Jon W. Ramsey \\ Oklahoma State University
}

\begin{abstract}
Literature supports benefits of mentoring for induction-year school-based agricultural education (SBAE) teachers. Yet for the past 15 years, no structured mentoring program has been offered for Oklahoma SBAE induction-year teachers. This study sought to find consensus among an expert panel representing Oklahoma SBAE regarding the impact on induction-year SBAE teachers without a structured mentoring program. Panel members were asked to respond to three open-ended questions representing goals, outcomes, and impacts of a mentoring program. Sixty-two unique statements representing eight themes met consensus. Themes included building mentoring relationships, effective emotional management, effective SBAE program management, impact to the profession, student learning, teacher retention, introduction to school climate, and reinforcing effective teaching behaviors. Oklahoma SBAE induction-year teachers and programs are negatively impacted from the lack of a structured mentoring program. The planning, funding, and implementation of a mentoring program for Oklahoma SBAE induction-year teachers should be a focus of professional development.
\end{abstract}

Keywords: mentoring, induction-year, Delphi, teacher retention

\section{Introduction and Review of Literature}

School-based agricultural education (SBAE) has experienced teacher shortages since the implementation of the Smith-Hughes Act in 1917 (Hillison, 1987; Solomonson et al., 2018). Recruitment programs, such as the National Association of Agricultural Educators' (NAAE) Teach Ag initiative, have been implemented to attract individuals to the profession (Ingram et al., 2018). However, high attrition rates continue to plague SBAE programs nationwide (Crutchfield, et al., 2013). Low teacher retention and high teacher turnover have been correlated with lower student achievement and negative impacts to school culture (Ronfeldt et al., 2013). Research reports anywhere from $30 \%$ to $50 \%$ of teachers leave the classroom in the first five years (Blackburn et al., 2017). This history of high teacher turnover rates supports an ongoing SBAE teacher shortage 
Journal of Research in Technical Careers

(Solomonson et al., 2018). At the beginning of the 2018-2019 school year, 71 SBAE teaching positions remained unfilled and 45 SBAE programs closed their doors (Smith et al., 2019).

Ultimately, and perhaps most importantly, the lack of highly qualified and effective SBAE teachers has a negative influence on students (Mishel et al., 2008). An estimated 48,000 students did not have access to a highly qualified local agricultural educator in the 2016-2017 school year (NAAE, 2018). Local communities (Martin \& Henry, 2012) and the larger agricultural sector (Goecker et al., 2015) are impacted when these students have little to no exposure to potential careers in agriculture, often the largest employing industry in rural communities (Huffman \& Orazem, 2007). SBAE programs have been shown to invest in local communities by providing opportunities for students to practice interpersonal skills while working with community leaders (Martin \& Henry, 2012). In the 2018-2019 school year, approximately 30,000 Oklahoma SBAE student Supervised Agricultural Experience (SAE) projects generated a \$63 million economic impact in state economy and included over 300,000 hours in community service activities (K. Murray, personal communication, January 17, 2020). Each year, 22,500 jobs in the agriculture industry are unfilled by agriculturally competent workers nationwide. SBAE students are needed to help these positions (Goecker et al., 2015).

A teacher's induction-year career stage requires the greatest support to provide proper education for students (Greiman et al., 2005; Katz, 1972). This support may come in the form of written materials, instructional planning time, training sessions, orientation programing, and mentorship opportunities (Joerger, 2003). According to Smith and Ingersoll (2004), mentoring involves the "personal guidance provided, usually by seasoned veterans, to beginning teachers in schools" (p. 683). Mentoring has the potential to "improve retention rates for new teachers along with their attitudes, feelings of efficacy, and instructional skills" (Darling-Hammond, 2010, p. 24). Many variables influence the effectiveness of the mentoring activities (Smith \& Ingersoll, 2004). The relationship between the mentor and protégé is one of the largest factors of an effective professional relationship for both parties (Hudson \& Hudson, 2017). Still, mentoring programs can serve to increase teacher retention (Foor \& Cano, 2012).

Solomonson et al. (2018) included teacher preparation and development as a contributing factor to the retention or attrition of a SBAE teacher. The induction-year requires the most intensive professional development of any career stage (Katz, 1972). According to Moir (2003), "quality induction programs promote greater teacher retention, breaking the cycle of attrition, which saves money for school districts and ensures that teacher shortages do not dictate hiring policy" (p. 1). Peiter et al. (2005) suggested mentoring, or the professional development relationship formed between experienced and novice colleagues, as an effective and efficient method to assist SBAE teachers in navigating the many challenges they encounter during their induction-year. According to Joerger (2002), professional development for induction-year SBAE teachers may "ensure elevated levels of personal satisfaction, student achievement scores and success" (p. 11). The induction-year can have lasting impacts throughout a teacher's novice years (Katz, 1972) and a teacher's sense of self-efficacy (Bandura, 1997). 
Requirements for induction-year and mentoring activities for SBAE teachers differ across state lines (Franklin \& Molina, 2012). Beginning in 1980, Oklahoma induction-year teachers were supported by a cohort of university faculty, school administration, and veteran teachers (House Bill 1706, 1980). This program was widely welcomed by Oklahoma teachers (Simms, 1983). However, the structured mentoring program for induction-year teachers was defunded through state budget cuts in 2004 (McKean, 2013). In subsequent years, no structured mentoring has been offered to induction-year SBAE teachers. First page, first paragraph: use this for the first paragraph of the paper.

\section{Theoretical Framework}

Katz's (1972) stages of development and training needs of preschool novice teachers served as the theoretical foundation for this study. Katz (1972) described the professional development of novice teachers in four stages, including survival, consolidation, renewal, and maturity. These stages begin in the preservice teaching phase and continue into the fifth year of professional teaching experience. Most induction-year teachers are categorized in the survival stage. In this stage, as the name implies, novice teachers are concerned with persevering through the day, week, and semester. They are most occupied with the current task at hand. Katz (1972) writes of theses teachers, "The discrepancy between anticipated successes and classroom realities intensifies feelings of inadequacy and unpreparedness" (p. 4).

Figure 1. Katz's (1972) stages of development and training needs for novice teachers

Mentoring is a vital training need throughout the survival and consolidation developmental stages. According to Katz (1972), "exchanges of information and ideas with more experienced colleagues may help teachers master the developmental tasks" ( $p$.

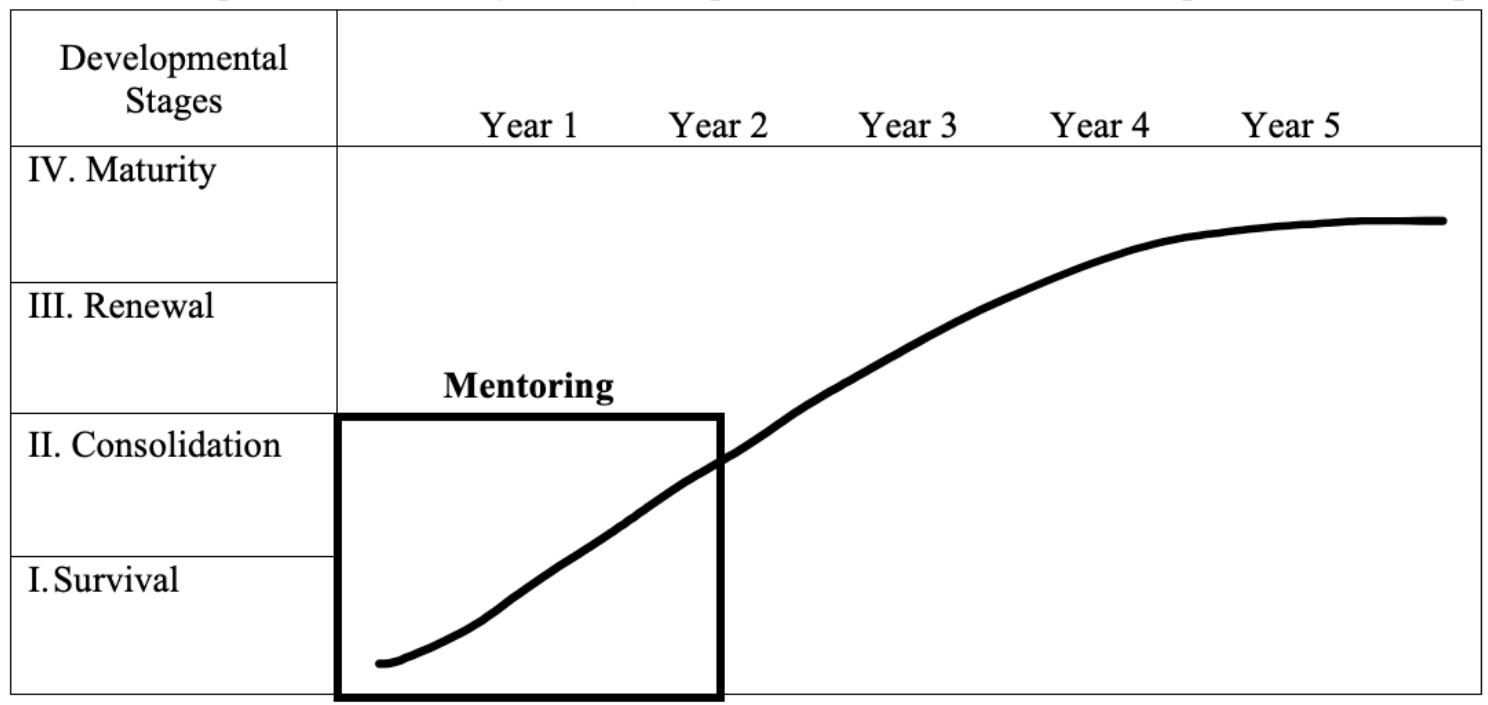


Journal of Research in Technical Careers

6). Training should be personalized to the individual novice teacher and their classroom. Katz (1972) recommends continuous training past intermittent prearranged classroom observations. Veteran teachers and consultants may provide professional development to teachers in the survival stage. Marshall et al. (1990) used this model to develop districtwide induction programing.

\section{Purpose and Objectives}

This study addresses the Agriculture, Food \& Natural Resources career cluster identified by the Journal of Research in Technical Careers. The purpose of this research was to describe the expert panels' perceptions regarding a lack of structured mentoring for Oklahoma induction-year SBAE teachers. The objectives were to:

1. Identify goals of a workplace-mentoring program for Oklahoma inductionyear SBAE teachers via a panel of experts.

2. Describe an expert panel's opinion on outcomes of a mentoring program for Oklahoma induction-year SBAE teachers.

3. Determine the impact of mentoring on SBAE induction-year teachers in Oklahoma as determined by a panel of experts.

\section{Method}

The modified-Delphi method was selected to achieve the purpose and objectives. As described by Hsu and Sandford (2007), the Delphi is "a widely used and accepted method for achieving convergence of opinion concerning real-world knowledge solicited from experts within certain topic areas" (p.1). It has been widely implemented in the field of agricultural education, especially in the area of curriculum planning (Martin \& Frick, 1998). Dalkey (1969) identified components of a reliable Delphi study: that is, anonymous response, iteration, controlled feedback, and statistical group response. Studies by Conner and Roberts (2013), Howerton et al. (2019), and Saucier et al. (2012) established the use of Delphi in assessing needs of preservice and beginning SBAE teachers.

An expert panel $(N=42)$ was identified from Oklahoma SBAE personnel. Participants were chosen from Oklahoma SBAE personnel and purposefully selected for their expertise and role within the profession. Twelve experienced SBAE teachers were chosen for their involvement in the previous mentoring program. Seven Oklahoma Department of Career and Technology Education (ODCTE) staff were identified based on their daily interactions with novice and experienced Oklahoma SBAE teachers. Seven teacher educators from three Oklahoma post-secondary institutions were included for their role in developing future agricultural educators. Second-year Oklahoma SBAE teachers $(n=9)$ were included on the panel to give voice to novice teachers' concerns. School administrators familiar with SBAE programs $(n=7)$ added administration viewpoints to the panel. To modify the Delphi method, participants were contacted through email and provided a link to complete the instrument electronically. 
Demographic data revealed round-one respondents were $86.36 \%$ males. SBAE teachers composed $45.45 \%$ of the sample with $22.73 \%$ ODCTE staff, $18.18 \%$ university professors, and $13.64 \%$ school administrators. These individuals have an average of 10.90 years of experience in their current position and 15.10 years of teaching experience. Traditional certification represented $88.57 \%$ of participants. Finally, $68.18 \%$ had experience in structured mentoring programs, either as a mentor, protégé, or both, and $86.36 \%$ participate in professional development activities at least once every few months.

Participants were contacted through email and directed to an instrument hosted through Qualtrics services. They were provided a Participant Information Sheet which had been approved by the Oklahoma State University Institutional Review Board. Each survey instrument was assessed for face and content validity. In round one, panelists were asked three open-ended questions to address the objectives of the study. Panelists also responded to seven demographic questions. Panelists provided comments to the following questions.

1. What are the overarching goals of a workplace-mentoring program?

2. What are three major outcomes of a mentoring program that are beneficial to a first-year teacher?

3. How does the absence of a structured mentoring program impact a first-year agricultural education teacher?

Responses were narrowed to unique statements and grouped into like themes (Diaz et al., 2018). Responses from 25 panel members were collected in this round for a response rate of $59.52 \%$. Only those who responded to the previous round were invited to participate in the subsequent round (Mantooth \& Fritz, 2006).

Round two sought to collect the panel's level of agreement on a six-point, summated scale to the 67 statements generated as a result of round one. Panelists were also given the opportunity to provide additional feedback on each of the eight themes identified from the round one responses (Roberts, 2006). Regarding consensus, a priori levels of $80 \%$ (Roberts \& Dyer, 2004) and 90\% (Easterly \& Myers, 2017) were averaged for a consensus level of $85 \%$. Items that at least $85 \%$ of the expert panel marked as somewhat agree, agree, or strongly agree were considered as meeting consensus. Items receiving less than 50\% agreement were dropped from the study (Easterly \& Meyers, 2017). Items scoring 51\% to $85 \%$ were included in the round three instrument that was distributed to 21 (50\% response rate) round two participants.

Round three sought to reach consensus or reject the remaining 14 statements. Panelists were asked to agree or disagree with each item (Easterly \& Meyers, 2017). Comments for each of the eight themes were collected. Sixteen respondents $(38 \%$ response rate) participated throughout the three rounds. Panels greater than 13 members are considered reliable (Dalkey, 1969). 


\section{Results}

Demographic data revealed round one respondents were $86.36 \%$ male. SBAE teachers composed $45.45 \%$ of the sample with $22.73 \%$ state ODCTE staff, $18.18 \%$ university professors, and $13.64 \%$ school administrators. These individuals have an average of 10.90 years of experience in their current position and 15.10 years of teaching experience. All but four were traditionally certified. Concomitantly, 68.18\% had experience in structured mentoring programs, either as a mentor, protégé, or both and $86.36 \%$ participate in professional development activities at least once every few months.

Round one produced 73 unique statements. The first question produced 11 statements, question two produced 30 statements, and the third question produced 32 statements. Statements were grouped into eight emerging themes. Emerging themes from these statements were building mentoring relationships, effective emotional management, effective SBAE program management, impact to agricultural education profession, improving student learning, increasing teacher retention, introduction to school climate, and reinforcing effective teaching behaviors.

In round two, each of the 73 responses from round one's three open ended questions was subjected to a six-point summated scale to assess the panel's level of agreement. Of these statements, 55 reached the consensus requirement of $85 \%$ agreement, four failed to be agreed upon by half the respondents and were dropped, and 14 were included in round three for final approval or rejection from the panel. Table 1 contains the statements which met consensus in round two.

Table 1. Items Meeting Consensus Following Round Two

\begin{tabular}{lccr}
\hline Item & $M(1-6)$ & $S D$ & Agreement \\
\hline \multicolumn{3}{c}{ Question 1: What are the overarching goals of a workplace-mentoring program? } \\
Enhance classroom instruction skills & 4.88 & 0.68 & 100.00 \\
Increase retention rates & 4.88 & 0.76 & 100.00 \\
Increase teacher success & 5.00 & 0.69 & 100.00 \\
Inform new and returning teachers about school & & & \\
$\quad$ procedures & 4.94 & 0.78 & 94.44 \\
Extend professional networks & 5.00 & 0.77 & 94.12 \\
Gain insight to teaching abilities & 4.88 & 0.76 & 94.12 \\
Gain meaningful professional relationships & 5.29 & 0.82 & 94.12 \\
Pair experienced and novice teachers & 4.88 & 0.90 & 88.24 \\
Support new teachers & 5.18 & 0.98 & 88.24
\end{tabular}


Question 2: What are three major outcomes of a mentoring program that are beneficial to a first-year teacher?

$\begin{array}{llll}\text { Active partnerships for periodic feedback } & 4.88 & 0.58 & 100.00 \\ \text { Assist new teachers set goals } & 4.76 & 0.64 & 100.00 \\ \text { Build lasting professional relationships } & 5.12 & 0.76 & 100.00 \\ \text { Clarify expectations } & 5.18 & 0.78 & 100.00 \\ \text { Deliver effective and enthusiastic lessons } & 4.76 & 0.73 & 100.00 \\ \text { Improve communication with stakeholders } & 5.06 & 0.70 & 100.00 \\ \text { Improve self-awareness of teaching performance } & 4.94 & 0.73 & 100.00 \\ \text { Improved student engagement } & 4.88 & 0.68 & 100.00 \\ \text { Improved time management } & 4.81 & 0.63 & 100.00 \\ \text { Improving student learning } & 4.71 & 0.46 & 100.00 \\ \text { Increase teacher collaboration } & 5.18 & 0.71 & 100.00 \\ \text { Provide knowledge of how a school functions } & 4.88 & 0.83 & 100.00 \\ \text { Readily available advice and opinions } & 5.18 & 0.71 & 100.00 \\ \text { Ability to teach students from diverse backgrounds } & 4.47 & 0.78 & 94.12 \\ \text { Accountability to instructional goals } & 4.47 & 0.61 & 94.12 \\ \text { Collegiality with fellow teachers } & 4.88 & 0.58 & 94.12 \\ \text { Effective classroom management } & 4.88 & 0.68 & 94.12 \\ \text { Greater general program knowledge } & 5.00 & 0.71 & 94.12 \\ \text { Improve abilities to mentor in the future } & 4.82 & 0.71 & 94.12 \\ \text { Improve self-efficacy } & 4.76 & 0.81 & 94.12 \\ \text { Improve teacher morale } & 4.82 & 0.86 & 94.12 \\ \text { Improve teacher satisfaction } & 4.59 & 0.84 & 94.12 \\ \text { Increase new teacher retention into the second year of } & & & \\ \quad \text { teaching } & 4.88 & 0.83 & 94.12 \\ \text { Strengthen community connections } & 4.81 & 0.88 & 94.12 \\ \text { Understand allocation of money } & 4.87 & 0.88 & 94.12 \\ \text { Additional organization } & 4.94 & 0.66 & 93.75 \\ \text { Increase student achievement } & 4.56 & 0.93 & 93.75 \\ \text { Continue education in content area } & 4.35 & 0.76 & 88.24 \\ \text { Encourage a healthy work-life balance } & 4.59 & 0.91 & 88.24\end{array}$

Question 3: How does the absence of a structured mentoring program impact a first-year agricultural education teacher?

$\begin{array}{llll}\text { Become overwhelmed with job-related activities } & 5.00 & 0.77 & 100.00 \\ \text { Feelings of helplessness } & 5.06 & 0.73 & 100.00 \\ \text { Time management for effective teaching } & 4.94 & 0.73 & 100.00\end{array}$


Hasten job-related apathy

$\begin{array}{lll}4.59 & 0.69 & 94.12\end{array}$

Assessment of teaching

$\begin{array}{lll}4.71 & 0.89 & 88.24\end{array}$

Erode self-confidence

$\begin{array}{ll}4.44 & 0.79\end{array}$

88.24

Foment feelings of burnout

$\begin{array}{ll}4.59 & 0.77\end{array}$

88.24

Lack of support

$\begin{array}{ll}4.59 & 0.97\end{array}$

88.24

Professional isolation

$4.76 \quad 0.94$

88.24

Affects student success

$4.69 \quad 0.98$

87.50

Creates an attitude of unimportance of new teachers' success

$\begin{array}{lll}4.50 & 0.87 & 87.50\end{array}$

Greatly enhances the responsibility of others to provide training

$\begin{array}{lll}4.38 & 0.99 & 87.50\end{array}$

Limits teachers' start in the profession

$4.50 \quad 0.79$

87.50

Miss deadlines

$4.38 \quad 0.99$

87.50

Negative community impacts

4.25

0.97

87.50

Negative impact on the profession

$4.31 \quad 0.77$

87.50

Informal mentoring already in place

$4.13 \quad 1.09$

86.67

Of the 14 statements included in round three, seven met final consensus and are listed in Table 2. Combined with the 55 consensus reaching statements from round two, the final list of statements reaching consensus includes 62 statements that $85 \%$ of the panel agree are true of mentoring SBAE teachers. All eight themes from round one met consensus. See Table 3 for a full list of items organized by theme and question.

Table 2. Items Meeting Consensus Following Round Three

\begin{tabular}{clc}
\hline Question & Item & Agreement (\%) \\
\hline 3 & Time consuming & 100.00 \\
3 & Lack of clarity regarding school functions & 93.75 \\
1 & Observe master teachers & 87.50 \\
2 & Develop new and returning teachers & 87.50 \\
3 & Contribute to program failure & 87.50 \\
3 & May contribute to poor or under performance & 87.50 \\
3 & More likely to make uninformed decisions & 87.50 \\
\hline
\end{tabular}


Table 3. Final Consensus List in Themes and Questions

\begin{tabular}{|c|c|c|}
\hline Theme & Question & Item \\
\hline \multirow{18}{*}{$\begin{array}{l}\text { Building Mentoring } \\
\text { Relationships }\end{array}$} & \multirow[t]{6}{*}{1} & -Develop new and returning teachers \\
\hline & & -Extend professional networks \\
\hline & & -Gain meaningful professional relationships \\
\hline & & -Observe master teachers \\
\hline & & -Pair experienced and novice teachers \\
\hline & & -Support new teachers \\
\hline & \multirow[t]{7}{*}{2} & -Active partnerships for periodic feedback \\
\hline & & -Assist new teachers set goals \\
\hline & & -Build lasting professional relationships \\
\hline & & -Collegiality with fellow teachers \\
\hline & & -Improve abilities to mentor in the future \\
\hline & & -Increase teacher collaboration \\
\hline & & -Readily available advice and opinions \\
\hline & \multirow[t]{5}{*}{3} & -Informal mentoring already in place \\
\hline & & -Lack of support \\
\hline & & -More likely to make uninformed decisions \\
\hline & & -Professional isolation \\
\hline & & -Time Consuming \\
\hline \multirow{8}{*}{$\begin{array}{l}\text { Effective } \\
\text { Emotional } \\
\text { Management }\end{array}$} & \multirow[t]{4}{*}{2} & -Encourage a healthy work-life balance \\
\hline & & -Improve self-efficacy \\
\hline & & -Improve teacher morale \\
\hline & & -Improve teacher satisfaction \\
\hline & \multirow[t]{4}{*}{3} & $\begin{array}{l}\text {-Become overwhelmed with job-related activities } \\
\text {-Erode self-confidence }\end{array}$ \\
\hline & & -Feelings of helplessness \\
\hline & & -Foment feelings of burnout \\
\hline & & -Hasten job-related apathy \\
\hline \multirow{8}{*}{$\begin{array}{l}\text { Effective SBAE } \\
\text { Program } \\
\text { Management }\end{array}$} & \multirow[t]{5}{*}{2} & -Additional organization \\
\hline & & -Improved time management \\
\hline & & -Greater general program knowledge \\
\hline & & -Strengthen community connections \\
\hline & & -Understand allocation of money \\
\hline & \multirow[t]{3}{*}{3} & -Contribute to program failure \\
\hline & & -Miss deadlines \\
\hline & & -Negative community impacts \\
\hline
\end{tabular}




\begin{tabular}{|c|c|c|}
\hline $\begin{array}{l}\text { Impact to } \\
\text { Agricultural } \\
\text { Education } \\
\text { Profession }\end{array}$ & 3 & $\begin{array}{l}\text {-Creates an attitude of unimportance of new teachers' } \\
\text { success } \\
\text {-Greatly enhances the responsibility of others to provide } \\
\quad \text { training } \\
\text {-Limits teachers' start in the profession } \\
\text {-Negative impact on the profession }\end{array}$ \\
\hline $\begin{array}{l}\text { Improving Student } \\
\text { Learning }\end{array}$ & 2 & $\begin{array}{l}\text {-Ability to teach students from diverse backgrounds } \\
\text {-Effective classroom management } \\
\text {-Improved student engagement } \\
\text {-Improving student learning } \\
\text {-Increase student achievement } \\
\text {-Affects student success }\end{array}$ \\
\hline $\begin{array}{l}\text { Increasing } \\
\text { Teacher Retention }\end{array}$ & $\begin{array}{l}1 \\
2\end{array}$ & $\begin{array}{l}\text {-Increase retention rates } \\
\text {-Increase teacher retention into the second year of teaching }\end{array}$ \\
\hline $\begin{array}{l}\text { Introduction to } \\
\text { School Climate }\end{array}$ & $\begin{array}{l}1 \\
2\end{array}$ & $\begin{array}{l}\text {-Inform new and returning teachers about school procedures } \\
\text {-Clarify expectations } \\
\text {-Improve communication with stake holders } \\
\text {-Provide knowledge of how a school functions } \\
\text {-Lack of clarity regarding school functions }\end{array}$ \\
\hline $\begin{array}{l}\text { Reinforcing } \\
\text { Effective Teaching } \\
\text { Behaviors }\end{array}$ & 1 & $\begin{array}{l}\text {-Enhance classroom instruction skills } \\
\text {-Gain insight to teaching abilities } \\
\text {-Increase teacher success } \\
\text {-Accountability to instructional goals } \\
\text {-Deliver effective and enthusiastic lessons } \\
\text {-Continue education in content area } \\
\text {-Improve self-awareness of teaching performance } \\
\text {-Assessment of teaching } \\
\text {-May contribute to poor or under performance } \\
\text {-Time management for effective teaching }\end{array}$ \\
\hline
\end{tabular}

Eleven items failed to meet consensus (a priori of $85 \%$ agreement) among the expert panel, four in round two and seven in round three. See Table 4 for a list of those items. Agreement on these items ranged from $12.50 \%$ to $81.25 \%$. It is important to note the items of Experience barriers to seeking help and Hasten the loss of new teachers to the third question narrowly missed consensus. Voices from the panel stated a lack of mentoring held no negative consequences for induction-year SBAE teachers and costs of structured mentoring outweighed benefits. However, the remaining members quickly 
drowned out this opinion. Each statement failed to reach 50\% agreement in round two. Other detractions to structured mentoring programs for induction-year SBAE teachers included potential personality conflicts between mentors and protégés and a belief mentoring may be more beneficial to SBAE teachers in the second year of their career.

Table 4. Items Failing to Meet Consensus

\begin{tabular}{clc}
\hline Question & Item & Agreement (\%) \\
\hline 3 & Experience barriers to seeking help & 81.25 \\
3 & Hasten the loss of new teachers & 81.25 \\
2 & Team decision making & 68.75 \\
3 & Decrease community connections & 68.75 \\
3 & Sets a bad example for the profession & 68.75 \\
3 & Personality conflicts between mentoring pairs & 50.00 \\
3 & Pursue unhealthy forms of self-medication & 50.00 \\
3 & More impactful in second year of teaching & 46.67 \\
3 & Teachers need to find their own mentors & 40.00 \\
3 & No impact from lack of mentoring & 20.00 \\
3 & Creates additional tasks for participants without additional & 12.50 \\
\hline
\end{tabular}

Table 5. Selected Comments from Panel Members

\begin{tabular}{|c|c|}
\hline Theme & Comment \\
\hline $\begin{array}{l}\text { Building Mentoring } \\
\text { Relationships }\end{array}$ & $\begin{array}{l}\text {-There may be some additional time commitment, but more for the } \\
\text { mentor than the new or returning teachers. The added benefit is a } \\
\text { successful teacher. }\end{array}$ \\
\hline $\begin{array}{l}\text { Effective Emotional } \\
\text { Management }\end{array}$ & $\begin{array}{l}\text {-I may "strongly agree" for one of the new teachers, and "strongly } \\
\text { disagree" for another example. } \\
\text {-New teachers seek advice from those whose advice is not always sound } \\
\text { or valuable. }\end{array}$ \\
\hline $\begin{array}{l}\text { Introduction to } \\
\text { School Climate }\end{array}$ & $\begin{array}{l}\text {-School climate, almost by definition, is likely to be very idiosyncratic } \\
\text { or unique. So, the value of the experiences and advice from a mentor } \\
\text { teaching in a school with a very different climate may have rather } \\
\text { limited application. } \\
\text {-Finance and policies regarding student overnight trips/chaperones are } \\
\text { areas that often times get young teachers in a bind when there is not a } \\
\text { structured mentoring program. } \\
\text {-It is hard for beginning teachers to comprehend all that the profession } \\
\text { entails, especially if they have been through an alternative pathway } \\
\text { for their teaching certification. }\end{array}$ \\
\hline $\begin{array}{l}\text { Impact to } \\
\text { Agricultural } \\
\text { Education } \\
\text { Profession }\end{array}$ & -Ag-Ed Staff does first year new teacher orientation. Very beneficial. \\
\hline
\end{tabular}


Panel members provided open-ended responses in relation to each theme following rounds two and three. A total of 18 comments were collected from these questionnaire items. To provide a voice for participants, selected responses to the openended questions are included in Table 5. Other comments were used to clarify statements or themes.

\section{Conclusions}

Objective one sought to identify consensus regarding goals of a workplacementoring program for SBAE teachers in Oklahoma. The first question provided the most agreement from the panel in round two $(M=4.92, S D=0.83)$ over the smallest number of unique statements in comparison to the other two questions. All ten statements met consensus. Therefore, panelists concur mentoring program goals should reflect school climate, teaching behaviors, building mentoring relationships, and teacher retention.

The second objective described the expert panel's opinion of the outcomes of a mentoring program for SBAE teachers. The second question generated the smallest average standard deviation $(M=4.82, S D=0.74)$ over the greatest number of unique statements, indicating close agreement among the panel. All but one statement met consensus. Panelists agreed there is a wide range of mentoring outcomes for inductionyear SBAE teachers, mirroring findings from Katz (1972) and Darling-Hammond (2010). This variety highlights the wide-ranging impacts for induction-year teachers. They believe all areas of an SBAE program may benefit from a structured mentoring program.

Objective three describes the panel's opinion on the impact of mentoring for Oklahoma SBAE teachers. The panel had the most disagreement on the third question. Of the 32 unique statements generated, 22 met consensus. This expert panel believes a lack of mentoring negatively impacts Oklahoma induction-year SBAE teachers. This lack of support may impact a teacher's trajectory through Katz's (1972) stages of development for novice teachers.

While the panel recognized Oklahoma's induction-year SBAE teachers commonly utilized informal mentorship, they also identified the shortcomings of current induction orientation practices. One member noted "new teachers seek advice from those who's advice is not always sound or valuable" while another wrote "first-year teachers get a lot of advice from different points of view. The message is not consistent." One panel expert summed up the importance of building mentoring relationships with "new teachers don't know what they don't know. Sometimes they don't know to ask or even what to ask."

\section{Recommendations}

There is some disagreement over specific concerns stemming from a lack of mentoring for induction-year SBAE teachers, providing a line of inquiry for future research. Qualitative methods would explore the challenges faced by induction-year SBAE teachers. The experiences of Oklahoma induction-year SBAE teachers should be 
compared to their counterparts in other states that employ a structured mentoring program.

It is recommended that the implementation of a structured mentoring program be further investigated for Oklahoma SBAE induction-year teachers with the goal of reflecting all themes expressed in the experts' responses. Katz (1972) proposes inductionyear teachers require "support, understanding, reassurance, comfort and guidance" (p. 4) through mentorship. A SBAE colleague would provide content specific guidance and program management advice as well as assist the induction-year teacher with incorporating him or herself into the profession (Kram \& Bragar, 1992). Induction-year SBAE teachers should also be supported within their school buildings and districts (Katz, 1972). A district mentor would guide induction-year teachers as they navigate school climate, procedures, finances, and cultures. In a similar approach to the now discontinued induction program in Oklahoma, teacher educators could act as instructional coaches to induction-year SBAE teachers as they navigate the challenges of classroom teaching (House Bill 1706, 1980).

This structured mentoring could occur through several platforms. Face-to-face sessions could be combined with both asynchronous and synchronous online communication as individual circumstances dictate (Cinkara \& Arslan, 2017). Both Oklahoma SBAE staff and teacher educators should invest resources to connect qualified veteran SBAE teachers to their induction-year colleagues. State funding as well as private and corporate donations should be explored to support this vital teacher professional development. Most importantly, a structured mentoring program shaped by mentoring research and the interests of SBAE teachers (Moore \& Swan, 2008) is needed to address the retention challenge facing the Oklahoma SBAE profession.

\section{References}

Bandura, A. (1997). Self-efficacy: The exercise of control. W.H. Freeman and Company.

Blackburn, J. J., Bunch, J. C., \& Haynes, J. C. (2017). Assessing the relationship of teacher selfefficacy, job satisfaction, and perception of work-life balance of Louisiana agriculture teachers. Journal of Agricultural Education, 58(1), 14-35. https://doi.org/10.5032/jae.2017.01014

Cinkara, E., \& Arslan, F. Y. (2017). Content analysis of a Facebook group as a form of mentoring for EFL teachers. English Language Teaching, 10(3), 40-53. https://doi.org/10.5539/elt.v10n3p40

Conner, N., \& Roberts, T. G. (2013). Competencies and experiences needed by pre-service agricultural educators to teach globalized curricula: A modified Delphi study. Journal of Agricultural Education, 54(1), 8-17. https://doi.org/10.5032/jae.2013.01008

Crutchfield, N., Ritz, R., \& Burris, S. (2013). Why agricultural educators remain in the classroom. Journal of Agricultural Education, 54(2), 1-14. https://doi.org/10.5032jae.2013.02001

Dalkey, N. C. (1969). The Delphi method: An experimental study of group opinion. The Rand Corporation. 
Journal of Research in Technical Careers

Darling-Hammond, L. (2010). Recruiting and retaining teachers: Turning around the race to the bottom in high-need schools. Journal of Curriculum and Instruction, 4(1), 16-32. https://doi.org/10.3776/joci.2010.v4n1p16-32

Diaz, J. M., Warner, L. A., \& Webb, S. T. (2018). Outcome framework for school garden program development and evaluation: A Delphi approach. Journal of Agricultural Education, 59(2), 143-165. https://doi.org/10.5032/jae.2018.02143

Easterly, R. G., \& Myers, B. E. (2017). Characteristics of enthusiastic and growing school-based agricultural education teachers: A Delphi approach. Journal of Agricultural Education, 58(2), 1-19. https://doi.org/10.5032/jae.2017.02001

Foor, R. M., \& Cano, J. (2012). Mentoring abilities and beliefs of Ohio secondary agricultural education mentor teachers. Journal of Agricultural Education, 53(1), 162-175. https://doi.org/10.5032/jae.2012.01162

Franklin, E. A., \& Molina, Q. F. (2012). Teacher induction programs in agricultural education: Description of the role of AAAE higher education teacher preparation programs. Journal of Agricultural Education, 53(1), 123-135. https://doi.org/10.5032/jae.2012.01123

Goecker, A. D., Smith, E., Fernandez, J. M., Ali, R., \& Theller, R. G. (2015). Employment opportunities for college graduates in food, agriculture, renewable natural resources, and the environment. United States Department of Agriculture.

https://www.purdue.edu/usda/employment/

Greiman, B. C., Walker, W. D., \& Birkenholz, R. J. (2005). Influence of the organizational environment on the induction stage of teaching. Journal of Agricultural Education, 46(3), 95-106. https://doi.org/10.5032/jae.2005.03095

Hillison, J. (1987). Agricultural teacher education preceding the Smith-Hughes Act. Journal of the American Association of Teacher Educators in Agriculture, 28(2), 8-17. https://doi.org/10.5032/jaatea.1987.02008

House Bill 1706, Chapter 284 (1980). https://old.oksenate.gov/publications/senate_journals/archived/sj1980v2.pdf

Howerton, T., Clemons, C. A., \& Linder, J. R. (2019). Perceived factors that influence the success of vertical transfer students in agricultural education: A Delphi study. Journal of Agricultural Education, 60(3), 32-46. https://doi.org/10.5032/jae.2019.03032

Hsu, C. C., \& Sandford, B. A. (2007). The Delphi technique: Making sense of consensus. Practical Assessment, Research \& Evaluation, 12(10). http://pareonline.net/getvn.asp?v=12\&n=4

Hudson, P. \& Hudson, S. (2017). Mentoring preservice teachers: Identifying tensions and possible resolutions. Teacher Development, 22(1), 16-20. https://doi.org/10.1080/13664530.2017.1298535

Huffman, W. E., \& Orazem, P. F. (2007). Agriculture and human capital in economic growth. Farmers, schooling, and nutrition. Handbook of Agricultural Economics, 3, 2281-2341. https://doi.org/10.1016/S1574-0072(06)03043-X

Ingram, M. L., Sorensen, T. J., Warnick, B. K., \& Lawver, R. G. (2018). The influence of schoolbased agricultural education on preservice agriculture teachers' choice to teach. Journal of Agricultural Education, 59(2), 64-78. https://doi.org/10.5032/jae.2018.02064

Joerger, R. (2003). A comparison of the occurrence and impact of selected forms of assistance as provided by school personnel to three cohorts of beginning agricultural education teachers. Journal of Career and Technical Education, 20(1), 7-22. https://journalcte.org/articles/10.21061/jcte.v20i1.620/ 
Kram, K. E., \& Bragar, M. C. (1992). Development through mentoring: A strategic approach. In D. H. Montross, \& C. J. Shinkman (Eds.), Career development: Theory and practice (pp. 221-254). Charles C. Thomas Publisher.

Katz, L. G. (1972). Developmental stages of preschool teachers (ED057922). ERIC. https://files.eric.ed.gov/fulltext/ED057922.pdf

Mantooth, L. J., \& Fritz, C. A. (2006). Challenges of service-learning in Tennessee 4-H youth development: A Delphi study. Journal of Agricultural Education, 47(3), 94-104. https://doi.org/10.5032/jae.2006.03094

Marshall, P., Fittinghoff, S., \& Cheney, C. O. (1990). Beginning teacher development stages: Implications for creating collaborative internship programs. Teacher Education Quarterly, 17(3), 25-35. https://www.jstor.org/stable/23475439

Martin, A. G., \& Frick, M. J. (1998). The Delphi technique: An informal history of its use in agricultural education research since 1984. Journal of Agricultural Education, 39(1), 73 79. https://doi.org/10.5032/jae.1998.01073

Martin, M. J., \& Henry, A. (2012). Building rural communities through school-based agriculture programs. Journal of Agricultural Education, 53(2), 110-123. https://doi.org/10.5032/jae.2012.02110

McKean, K. (2013). Educational reform in Oklahoma a review of major legislation and educational performance since 1980. Oklahoma Technical Assistance Center. https://okpolicy.org/wp-content/uploads/2013/03/EdReform_OTAC_fullbrief.pdf

Mishel, L., Allegretto, S., \& Corcoran, S. (2008). The teaching penalty: We can't recruit and retain excellent educators on the cheap. Education Week, 27(35), 26-28. https://www.edweek.org/ew/articles/2008/04/30/35mishel_ep.h27.html

Moir, E. (2003). Launching the next generation of teachers through quality induction (ED479764). ERIC. https://files.eric.ed.gov/fulltext/ED479764.pdf

Moore, L. L., \& Swan, B. G. (2008). Developing best practices of teacher induction. Journal of Agricultural Education, 49(4), 60-71. https://doi.org/10.5032/jae.2008.04060

National Association of Agricultural Educators (NAAE). (2018). 2018 national teach ag campaign. Author. https://www.naae.org/teachag/news/2018_TeachAgOverview.pdf

Peiter, R. L., Terry, R., Jr., \& Cartmell, D. D. II. (2005). Mentoring first year agricultural educators: Examining a state mandated induction program. Journal of Agricultural Education, 46(1), 11-19. https://doi.org/10.5032/jae.2005.01011

Rayfield, J., McKim, B. R., Lawrance, S., \& Stair, K. (2014). Developing attitudinal metrics for induction-year agricultural education teachers. Journal of Agricultural Education, 55(1), 38-50. http://doi.org/10.5032/jae.2014.01038

Roberts, T. G. (2006). Developing a model of cooperating teacher effectiveness. Journal of Agricultural Education, 47(3), 1-13. https://doi.org/10.5032/jae.2006.03001

Roberts, T. G., \& Dyer, J. E. (2004). Characteristics of effective agriculture teachers. Journal of Agricultural Education, 45(4), 82-95. https://doi.org/10.5032/jae.2004.04082

Ronfeldt, M., Loeb, S., \& Wyckoff, J. (2013). How teacher turnover harms student achievement. American Educational Research Journal, 50(1), 4-36. https://doi.org/10.3102/0002831212463813

Saucier, P. R., McKim, B. R., \& Tummons, J. D. (2012). A Delphi approach to the preparation of early-career agricultural educators in the curriculum area of agricultural mechanics: Fully qualified and highly motivated or status quo? Journal of Agricultural Education, 53(1), 136-149. https://doi.org/10.5032/jae.2012.0136

Simms, R. L. (1983). Attitudes of Oklahoma teachers towards House Bill 1706. Journal of Teacher Education, 34(2), 26-28. 
Smith, A. R., Lawver, R. G., \& Foster, D. D. (2019). National agricultural education supply and demand study, 2018 executive summary. http://aaaeonline.org/resources/Documents/NSD2018\%20Summary\%20(1).pdf

Smith, T. M., \& Ingersoll, R. M. (2004). What are the effects of induction and mentoring on beginning teacher turnover? American Educational Research Journal, 41(3), 681-714. https://doi.org/10.3102/00028312041003681

Solomonson, J. K., Korte, D. S., Thieman, E. B., Retallick, M. S., \& Keating, K. H. (2018). Factors contributing to Illinois school-based agriculture teachers' final decision to leave the classroom. Journal of Agricultural Education, 59(2), 321-342.

https://doi.org/10.5032/jae.2018.02321 